\title{
ISAIANIC VARIATIONS IN THE LETTER OF JAMES
}

\author{
J Ú L I U S P A V E L Č Í K
}

\section{ABSTRACT}

The article treats two short texts in the Letter of James, namely 5:4 and 1:10-11, relevant for an investigation of the possible allusions of this New Testament writing to the Greek version of the book of the prophet Isaiah. Comparing them with the corresponding Isaianic parallels leads to the conclusion that the author of the letter was well acquainted with them and used them in adapted form in his new theological and ethical-pragmatical context.

\section{Key words}

Letter of James; Isaiah; Sabaoth; Rich; Flower; Grass

DOI: $10.14712 / 23363398.2020 .9$

$\mathrm{I}$

$t$ is undeniable that the author of the Letter of James had a thorough knowledge of the Old Testament. This is evident not only from the direct quotations from the Torah ${ }^{1}$ and the biblical characters explicitly mentioned (Abraham, Rahab, Job, Elijah), but also from many other allusions, mainly to Old Testament prophetic and sapiential literature. ${ }^{2}$ There is a consensus of scholars about the Old Testament quotations in the Letter of James being taken from the

\footnotetext{
1 See below.

2 See very good overviews in Joseph B. Mayor, The Epistle of St. James. The Greek Text with Introduction Notes and Comments (London: Macmillan and Co., Third Edition, 1910), cx-cxviii; Joseph Chaine, L'épitre de Saint Jacques (Paris: J. Gabalda et Fils, 1927), XLI-LXIV.
} 
Septuagint. ${ }^{3}$ Against this background, we are interested in the manner and the measure of the use of the Greek translation of the book of the prophet Isaiah by the author of this New Testament writing.

Beyond the relatively short notes in commentaries on the Letter of James, there is no special study of this problem except for Kenneth Fitzhugh Morris' dissertation, ${ }^{4}$ whose conclusion is that 'the composer of James was well-enough acquainted with the Septuagint of Isaiah that

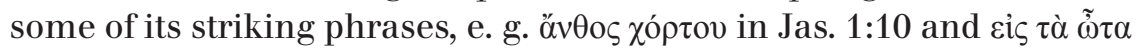

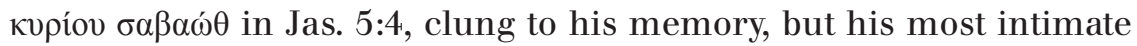
knowledge was of the Targum of Isaiah'. ${ }^{5}$ The topic is also attractive because of the fact that the editors in the monograph Isaiah in the New Testament did not intentionally include the chapter dedicated to the representation of this prophet in the Letter of James. ${ }^{6}$

This article does not claim to treat exhaustively all the possible allusions of James to the book of the prophet Isaiah. ${ }^{7}$ Some of them would surely be very interesting, but a careful, thorough, and comprehensive evaluation of their relevance would exceed the scope of a single academic study. Therefore, this article pursues just two loci of the Letter of James, namely 5:4 and 1:10-11, which can be considered highly relevant for the investigation of the author's acquaintance with the Isaianic thoughts. These two loci will be compared with the LXX texts of Isaiah 5:9 and 40:6-7 respectively as their possible quotation sources. The goal of this comparison is to establish the way in which the author of the letter uses the text of Isaiah to support his argument. I will catalogue and evaluate both the similarities and the differences between the verses in James and the corresponding verses of Isaiah. Attention

3 James Hardy Ropes, A Critical and Exegetical Commentary on the Epistle of St. James (New York: Charles Scribner's Sons, 1916), 25-26; Jean Cantinat, Les épîtres de Saint Jacques et de Saint Jude (Paris: J. Gabalda, 1973), 17; Rainer Metzner, Der Brief des Jakobus (Leipzig: Evangelische Verlagsanstalt, 2017), 32-33; Dale C. Allison, A Critical and Exegetical Commentary on the Epistle of James (New York/London/New Delhi/Sydney: Bloomsbury, 2013), 51-54.

4 Kenneth Fitzhugh Morris, An Investigation of Several Linguistic Affinities between the Epistle of James and the Book of Isaiah (A Dissertation Presented to the Faculty of the Graduate School Union Theological Seminary, Richmond, Virginia, 1964).

5 Morris, Investigation, 253.

6 Cf. Steve Moyise and Maarten J. J. Menken, Isaiah in the New Testament (London/ New York: T\&T Clark, 2005), 5.

7 Luke Timothy Johnson, The Letter of James. A New Translation with Introduction and Commentary (New York: Doubleday, 1995), 358-359 lists more than 90 references to Isa. The most full-range discussion about this topic is presented in chapter 'The Evidence for Jacobean Affinities with Isaiah' in Morris, Investigation, 144-187. 
will be especially paid not only to the wording but also to the context as well as to the purpose of the short texts in question.

In the first part of the article, I am going to present short commentaries of the phrases used by the author of the letter in order to introduce his Old Testament quotations explicitly. This is the starting point for further reflections based primarily on the fact that the 28th edition of Aland's Novum Testamentum Graece 8 italicises the two other phrases in the Letter of James as direct quotations from the Old

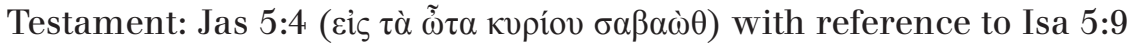

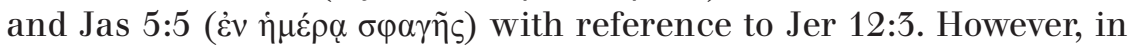
neither case can we find any introduction reminding the reader of the direct Old Testament quotation as in the other cases. Therefore, in the second part of this study I am going to seek the answer to the question about James' knowledge and deliberate use of these Isaianic words in Jas 5:4. In the third part, I am going to deal in a similar manner with the verses Jas 1:10-11, which show a striking similarity to the passage in Isa 40:6-7.

\section{Part I}

The starting point of the present analysis is to show the way the author of the letter deals with the Old Testament quotations:

\section{Jas 2:8 (Lev 19:18)}

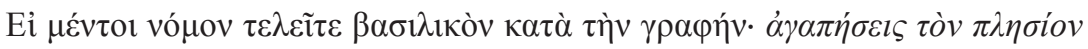

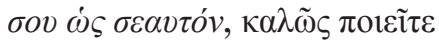

'If you really fulfill the royal law according to the Scripture, "You shall love your neighbor as yourself", you are doing well.9

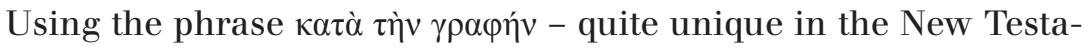
ment ${ }^{10}$ - the author of the letter clearly confirms his recognition of the authority of the commandment of Lev 19:18, yet in a specific way. The other direct Old Testament quotations in the Letter of James are

8 Barbara Aland et al., Novum Testamentum Graece. 28th ed. (Stuttgart: Deutsche Bibelgesellschaft, 2012).

9 Unless otherwise stated, all English translations of both the Hebrew Old Testament and of the New Testament are taken from the English Standard Version (2011) in BibleWorks 9.0.

10 In this form it can be found only in this verse. There is a similar phrasing in plural in

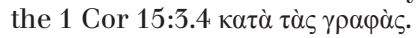


introduced by various forms of the verb $\lambda \varepsilon \dot{\gamma \varepsilon ı v, ~ n o t ~ b y ~ w o r d s ~ w i t h ~ t h e ~}$ root $\gamma \rho \alpha \varphi-($ e.g., $\gamma \rho \alpha \varphi \eta$, $\gamma \varepsilon \dot{\gamma} \rho \alpha \pi \tau \alpha)$, which is the usual occurrence in other New Testament writings. Furthermore, in two other verses the prep-

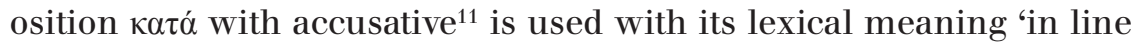
with, in accordance with, in keeping with'12 (James 2:17; 3:9). ${ }^{13}$ Based

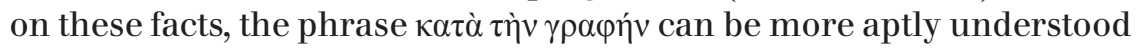
in the normative sense ('if you really fulfill the royal law in accordance with the statement of the Scripture'), not as an introduction of the direct quotation ('if you really fulfill the royal law which reads'). ${ }^{14}$

\section{Jas 2:11a (Deut 5:17-18, resp. Exod 20:13,15) ${ }^{15}$}

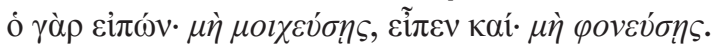

'For he who said, "Do not commit adultery," also said, 'Do not murder'.'

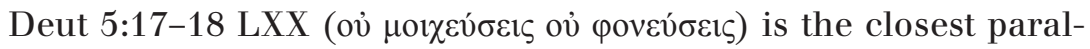
lel because of the prohibition of adultery which immediately precedes the prohibition of murder. ${ }^{16}$ Different form $\mathrm{s}^{17}$ would be indicative of an allusion of this Old Testament passage rather than their direct quotations. ${ }^{18}$ As for both the order of the commandments and the verbal forms, James' wording is exactly identical to that of Luke 18:20. As re-

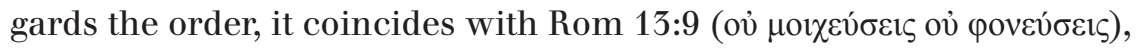
the forms of which are identical with those of Deut 5:17-18 LXX. In

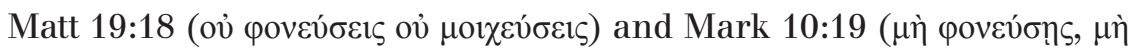

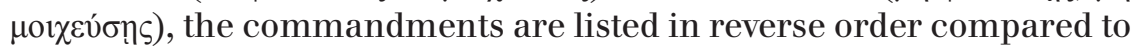
that of the Hebrew (Masoretic) version of Deut 5:17-18. ${ }^{19}$

11 It is used with the genitive in James 3:14 and 5:9 (meaning 'against').

12 Frederick William Danker, The Concise Greek-English Lexicon of the New Testament (Chicago and London: The University of Chicago Press, 2009), 188.

13 This basic meaning is naturally modified in English translations with regard to the English phraseology. ESV translates Jas 2:17: 'So also faith by itself, if it does not have works, is dead.' Jas 3:9: 'With it we bless our Lord and Father, and with it we curse people who are made in the likeness of God.' (Italics are mine.)

14 Cf. Johnson, Letter, 231; Patrick J. Hartin, James (Collegeville, Minnesota: Liturgical Press, 2003), 121.

15 Cf. Július Pavelčík, “Dokonalý zákon slobody” (Jak 1,25). K chápaniu zákona v Jakubovom liste,' Studia Biblica Slovaca 3, no. 2 (2011): 207-208.

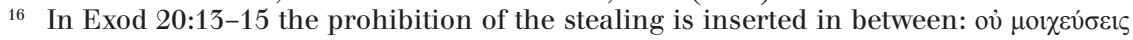

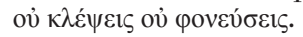

17 The aorist subjunctive expressing the negative imperative in James; the future indicative in Deuteronomy.

18 Cain H. Felder, 'Partiality and God's Law: An Exegesis of James 2:1-13,' Journal of Religious Thought 39 (1982-83): 63-64.

19 Cf. Johnson, Letter, 233. 


\section{Jas 2:23 (Gen 15:6)}

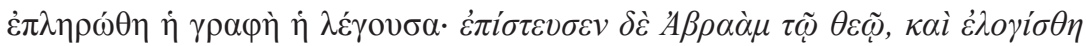

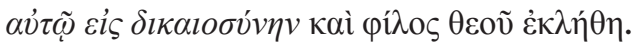

'The Scripture was fulfilled that says, "Abraham believed God, and it was counted to him as righteousness" - and he was called a friend of God.'

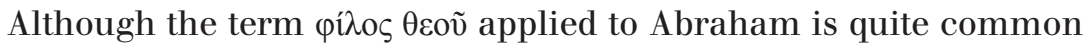
in Jewish literature, the verbatim wording is not found anywhere in the Septuagint. ${ }^{20}$

\section{Jas 4:5 (?)}

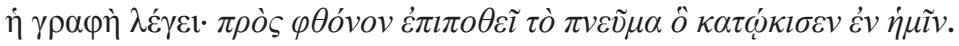

'Or do you suppose it is to no purpose that the Scripture says, "He yearns jealously over the spirit that he has made to dwell in us"?'

There are some interpretive problems with Jas 4:5 connected both with the question whether the quoted sentence is really present in the Old Testament and with the interpretation of the noun $\pi v \varepsilon \tilde{v} \mu \alpha$ being

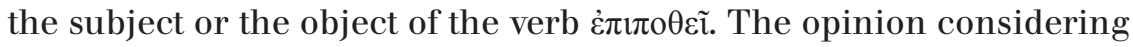
the human spirit ${ }^{21}$ being the subject seems to be more convincing. In this case, the verse speaks about God, who 'caused this spirit to dwell' in us and its presence in us can be a source of jealousy. The assumption that it is human jealousy it is concerned with here is supported by the contextual affinity with Jas 3:14-4:10.

\section{Jas 4:6 (Prov 3:34)}

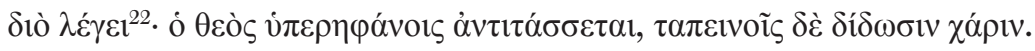

'Therefore it says, "God opposes the proud, but gives grace to the humble".'

20 Morris, An Investigation, 150-151; cf. Mayor, The Epistle, 105.

21 Cf. Wiard Popkes, Der Brief des Jakobus (Leipzig: Evangelische Verlagsanstalt, 2001), 272; Christoph Burchard, Der Jakobusbrief (Tübingen: Mohr Siebeck, 2000), 174; Rinaldo Fabris, Lettera di Giacomo: Introduzione, versione, commento (Bologna: Edizioni Dehoniane, 2004), 281; Allison, Commentary, 621. Other commentators hold the God spirit to be the subject of the verb غ̇ंıло $\theta \dot{\varepsilon} \omega$, for example, Jacqueline Assaël and Élian Cuvillier, L'Épître de Jacques (Genève: Labor et Fides, 2013), 232; Scot McKnight, Letter of James (Grand Rapids, Michigan / Cambridge, U. K.: Wm. B. Eerdmans Publishing Co, 2011), 337-338.

22 Because of the immediate connection with 4:5 the subject of $\lambda \dot{\varepsilon} \gamma \varepsilon \iota$ is $\gamma \rho \alpha \varphi \eta$. 


\section{Part II}

\section{Jas 5:4}

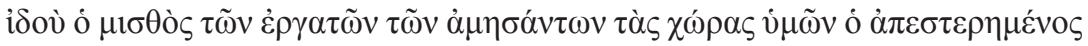

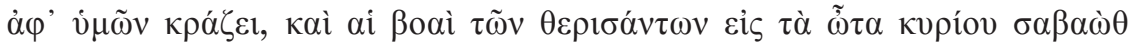

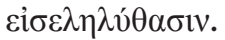

'Behold, the wages of the laborers who mowed your fields, which you kept back by fraud, are crying out against you, and the cries of the harvesters have reached the ears of the Lord of hosts.'

\section{Isa 5:9 LXX $X^{23}$}

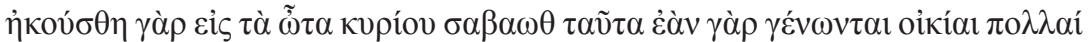

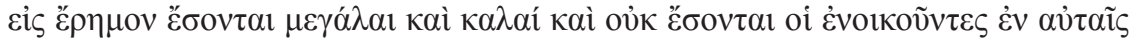

'For these things were heard in the ears of the Lord Sabaoth; for if houses become many, large and beautiful ones shall be desolate, and there shall be no inhabitants.'

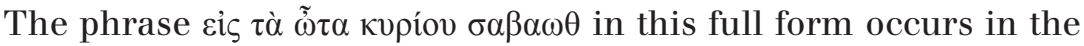
Septuagint only in the aforementioned verse of the book of the prophet Isaiah. The very title кúpı $\sigma \alpha \beta \alpha \omega \theta \theta$ in the Septuagint is both the semi-transcription and the semi-translation of the Hebrew ידוָה צִבְָאוֹ therefore, it can be found only where it depends upon the Masoretic text. Out of $240^{24}$ occurences of the term יִהוָה צִבְָאוֹת in the Hebrew Bible, 144 are in Isaiah and Jeremiah. Its most frequent Greek translation

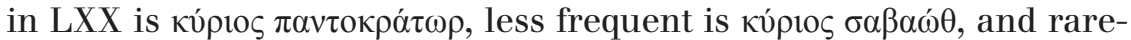

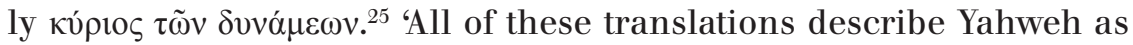
a deity of great power, taking Zebaoth element as a personal name, as a plural of an appellative with the meaning "power". ${ }^{26}$ The usual English translation of the יהוָה צְבָָאוֹת (the plural of 'army') is 'Lord of

25 The text of the Septuagint is from Alfred Rahlf, Septuaginta. Id est Vetus Testamentum graece iuxta $L X X$ interpretes (Stuttgart: Deutsche Bibelgesellschaft, 1979). All English translations of the Septuagint are taken from the Electronic Edition of the New English Translation of the Septuagint available at http://ccat.sas.upenn.edu/nets /edition.

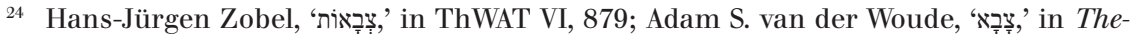
ologisches Handwörterbuch zum Alten Testament II, ed. E. Jenni and C. Westermann (München: Chr. Kaiser Verlag / Zürich: Theologischer Verlag, 1976), 499.

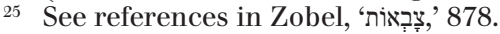

26 Tryggve N. D. Mettinger, 'Yahveh Zebaoth,' in Dictionary of Deities and Demons in the Bible, ed. Karel Van Der Toorn, Bob Becking, Pieter W. Van Der Horst, Second Extensively Revised Edition (Leiden/Boston/Köln: Brill / Grand Rapids, Michigan / Cambridge, UK: Wm. B. Eerdmans Publishing Co., 1999), 920. 
hosts'. Modern translations of the Septuagint version normally retain a transcription of the word $\sigma \alpha \beta \alpha \omega \theta \theta$ ('Lord Sabaoth'; ${ }^{27}$ 'Herr Sabaoth', ${ }^{28}$ 'Pán Sabaóth'29).

There are in principle four possibilities of specifying the precise meaning of the צִבְָאו: '(a) the armies of Israel, (cf. 1 Sam 17:45); (b) the heavenly hosts, whether the hosts of stars or the heavenly council of Yahweh (cf. Ps 89:9); (c) the "domesticated" mythical forces of nature in Canaan; or (d) all creatures on earth and in the heavens (cf. Gen 2:1). ${ }^{30}$

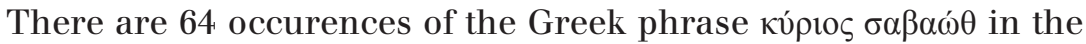
LXX, most of which (52) unquestionably occur in the book of the prophet Isaiah. ${ }^{31}$ This fact can be therefore regarded as a strong, unique feature of the Greek translation of this prophetical book.

Isa 5:9 belongs to the microcontext of the verses in Isa 5:8-10, ${ }^{32}$ where the prophet speaks about unjust and unlawful hoarding of property (5:8) going to be destroyed (5:9b-10) after the intervention of 'the Lord Sabaoth', because these things were heard in His ears (5:9a). ${ }^{33}$ Although the 'rich' are not explicitly mentioned, it is evident that the statement is directed against rich landowners depriving their neighbours not only of their property, but also of their dignity. ${ }^{34}$ For this reason Hades is waiting for them, as we can read in Isa 5:14 LXX, where the rich are explicitly referred to in the additional words which have

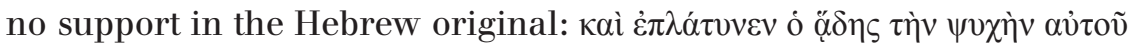

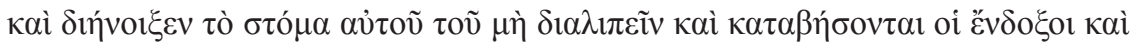

27 NETS, ad locos.

28 Septuaginta Deutsch. Das griechische Alte Testament in deutscher Übersetzung, ed. Wolfgang Kraus and Martin Karrer (Stuttgart: Deutsche Bibelgesellschaft, 2009), ad locos.

29 Ivana Vlková and Jana Plátová, Izaiáš. Komentovaný preklad recké septuagintní verze (Praha: Vyšehrad, 2018), ad locos.

30 Mettinger, 'Yahveh,' 920; cf. Zobel, 'צְבָאוֹת,' 880-881; Woude, 'צָבָָ', 504-506.

31 According to the statistics of BibleWorks.

32 This is embedded into the broader context of the six 'woes' (NETS: 'Ah') of 5:8-24 pronounced against various kinds of injustice. The much broader context of these 'woes' is framed by the chapters Isa 1-12 proclaiming the words both of the judgment and the salvation of God's people. Cf. Joseph Blenkinsopp, Isaiah 1-39. A New Translation with Introduction and Commentary (New York; London; Toronto; Sydney; Auckland: Doubleday, 2000), 171-174.

33 The Hebrew original contains a different wording: has sworn in my hearing. Man/prophet, and not God is the listener here.

34 Cf. Rudolf Kilian, Jesaja 1-12 (Würzburg: Echter Verlag, 1986), 42. 


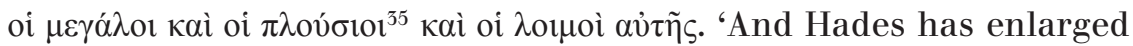
its appetite ${ }^{36}$ and opened its mouth without ceasing; and her ${ }^{37}$ glorious ones and her great and her rich and her pestilent shall go down.'

The 'rich' are explicitly mentioned in the pericope 5:1-6 of the Letter of James and, analogous to Isa $5: 8^{38}$, their antisocial behaviour is a source of criticism, but now the case is their withholding of and not paying fair wages to those who had harvested their field (Jas 5:4).

There are three points common to these two biblical texts: (i) the

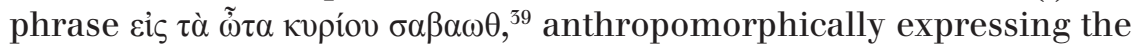
belief that God turns his attention to the complaints of the oppressed and afflicted by any kind of unjust treatment; ${ }^{40}$ (ii) the topic of increasing the misery of the poor on the part of the rich (by the distraint of property or not paying the due wage) which can be called 'the sins that cry to heaven'41 because they reach 'the ears of the Lord Sabaoth'; (iii) some punishments of the rich to be expected (Isa 5:9-10,14; Jas 5:1$3,5 \mathrm{~b})$ describing the annihilation of their property unjustly hoarded. Based on these similarities, regarding both the very wording and the contextual setting, Isa 5:9 LXX - perhaps as the only one of possible Isaianic references in the Letter of James - can aspire to the title of 'the direct quotation of the prophet Isaiah'. ${ }^{42}$

The present investigation also cannot omit another interesting potential parallel of the Old Testament with a similar reading, i.e.,

35 There are only five occurences of the word $\pi \lambda$ ov́ of Isa $5: 14 ; 32: 9,13 ; 33: 20 ; 53: 9$.

36 Septuaginta Deutsch. Erläuterungen und Kommentare zum griechischen Alten Testament. Band II: Psalmen bis Daniel, ed. Martin Karrer and Wolfgang Kraus (Stuttgart:

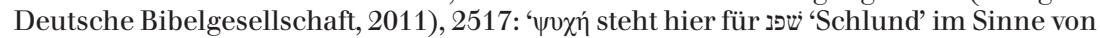
Begierde.'

37 Septuaginta Deutsch. Übersetzung, 1235 notes: 'Gen. Fem. Sg., bezogen wohl auf Judäa bzw. Jerusalem.' Similarly, NETS ad locum.

38 'Ah, those who join house to house and bring field next to field so that they may take something from their neighbor! Will you dwell alone on the earth?' (NETS).

39 The only other occurrence of the кúpı $\sigma \alpha \beta \alpha \omega \theta$ can be found in the New Testament in

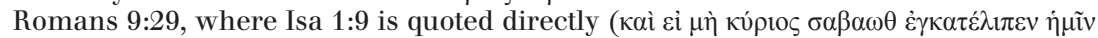

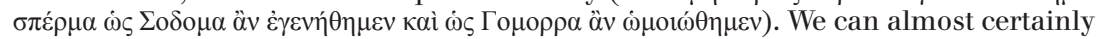
rule out any kind of dependence of Jas 5:4 on Romans 9:29 on the basis of wholly different wording and particularly of the different thematic context. Morris, Investigation, 153-154: 'The context is so entirely other than that of Jas. 5:4 that it is impossible to believe that the composer of James could have derived his phraseology from it.' Cf. Feliks Gryglewicz, Listy katolickie (Poznań: Pallottinum, 1959), 125.

41 Cf. Catechism of the Catholic Church, 1867 for this group of sins.

42 Morris, Investigation, 153: 'The words of Jas. 5:4 find no parallel worthy of note in the remainder of the Jewish literature, the secular Hellenistic literature or the non-canonical early Christian writings.' 


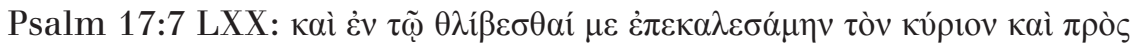

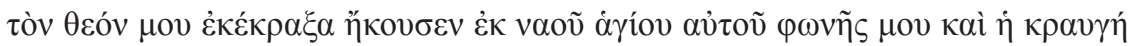

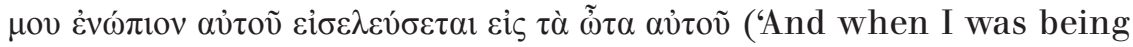
afflicted, I called upon the Lord, and to my God I cried. From his holy shrine he heard my voice, and my cry before him will enter into his ears.'). On the one hand the titles 'Lord' and 'God' are without the attribute $\sigma \alpha \beta \alpha \omega \theta$ in this verse and 'Lord' is in our treated phrase present only implicitly in the genitive of the 3 rd person of the pronoun ( $\alpha$ vioṽ).

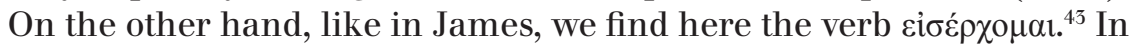
both cases, the subject is 'a cry', yet expressed with two different terms

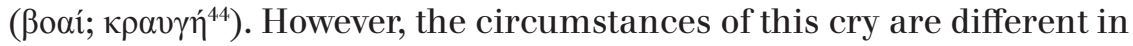
both texts. In Psalm 17 LXX, it is a part of the the individual's hymn of the Lord ('David the servant of the Lord') for being rescued from the hands of his enemies (v. 1; cf. vv. 8-51). By this action God responded to the Psalmist's cry in his difficulties. The cries of the harvesters in Jas 5:4 who did not receive their wage are a part of the very fierce criticism of the rich.

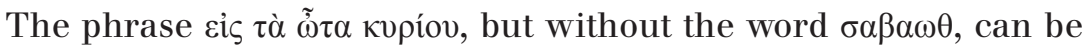
found also in 1Rgns (= 1Sam) 8:21 LXX. ${ }^{45}$ In Num 14:28 $8^{46}$ and 1Rgns (= 1Sam) 25:24, LXX, the Lord, or lord (i.e., David) is in this phrase clearly present in the dialogical form as the personal pronoun of the 1st, or 2nd person ( $\mu$ ov, or $\sigma o v$ ) because of being previously explicitly mentioned in the first part of both verses. All three verses share the use of the verb $\lambda \alpha \lambda \dot{\varepsilon} \omega$ ( $\dot{\varepsilon} \lambda \dot{\alpha} \lambda \eta \sigma \varepsilon v, \lambda \varepsilon \lambda \alpha \lambda \eta \dot{\kappa} \kappa \alpha \tau \varepsilon$, resp. $\lambda \alpha \lambda \eta \sigma \alpha ́ \tau \omega)$. Nevertheless, their wording and context do not have such force as to be seriously taken into account as relevant parallels with Jas 5:4.

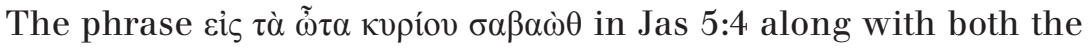
statistics and locations of the word $\sigma \alpha \beta \alpha \omega \theta$ in the Septuagint and the similar context indicate that the author of the Letter of James had very good knowledge of the Greek version of the book of the prophet Isaiah and used its ideas in the formulations of his writing. In addition to the 5th chapter, as we can see below, the whole pericope of Jas 5:1-6

43 In the form of the future tense, not perfect as in Jas.

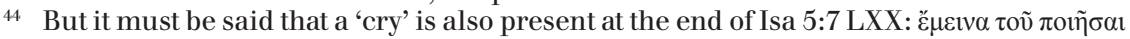

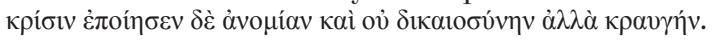

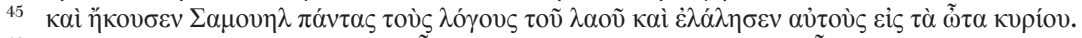

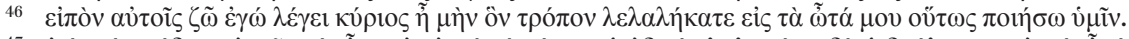

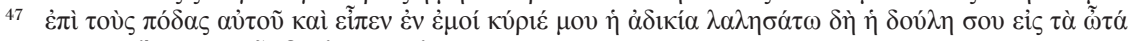

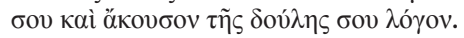


contains also other possible allusions to this prophetical book ${ }^{48}$ which can be used as supporting indirect arguments for the conclusion of this article.

\section{II.1}

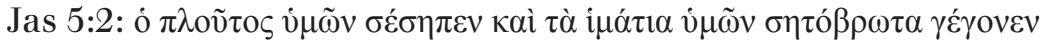

'Your riches have rotted and your garments are moth-eaten.'

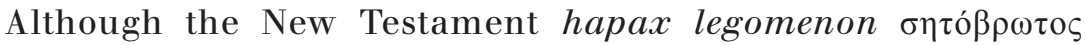
('moth-eaten') has its only verbatim parallel in the LXX in Job 13:28

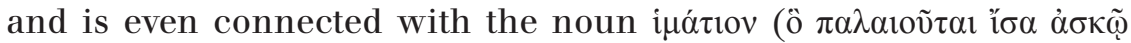

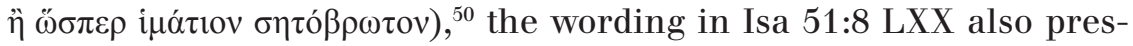

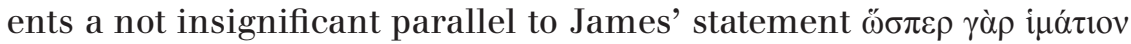

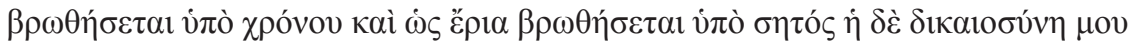

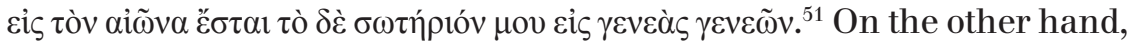
it must be mentioned that the very image of corruptive activity of moths can be found in other places of the Septuagint too, for example, Proverbs 25:20; Sir 42:13; Isa 33:1; 50:9, ${ }^{52}$ and also in the New Testament in Matt 6:19-20. ${ }^{53}$ However, none of these texts contain the same or a similar connection with the wealth of the rich as in the Letter of James. Both this fact as well as similar terminology and wording suggest a narrower dependence of Jas 5:2 on Job and Isaiah. However, the traditionally widespread image of destruction, perishableness, and transience, appearing after all also in Jesus' teaching ${ }^{54}$ could to a certain degree weaken this relation.

48 It is absolutely unquestionable that this pericope, containing accusation and warning, is very similar to the Old Testament prophetical proclamations of doom. See McKnight, James, 381; Hubert Frankemölle, Der Brief des Jakobus. Kapitel 2-5 (Gütersloh: Gütersloher Verlagshaus, 1994), 646.

49 It is the Septuagint hapax legomenon too. Frankemölle, Brief, 2-5, 648 ponders on the dependence of Jas 5:2 only on Job 13:28: 'Dürfte Ijob 13,28 als Tradition für Jak 5,2b feststehen, falls Jakobus - da dort und hier das Bild anders verwendet wird (Ijob bzw. der Mensch wird alt wie ein von Motten zerfressenes Kleid) - nicht sprachschöpferisch aus eigener Intention das Bild in 5,2 formuliert hat.'

50 'A worn out thing, like a skin, I am, or like a moth-eaten garment.'

51 'For just as a garment it will be devoured by time, and like wool it will be devoured by a moth, but my righteousness will be forever and my salvation for generations of generations.'

52 Cf. Johnson, Letter, 299.

53 Frankemölle, Brief, 2-5, 648: 'Die traditionsgeschichtliche Vorlagen des Jakobus lassen sich unschwer festmachen, mögen auch einzelne Motive in der prophetischen und weisheitlichen wie auch in der synoptischen Tradition vielfach belegt sein.'

54 Gerhard Maier, Der Brief des Jakobus (Witten: SCM R. Brockhaus / Giessen: Brunnen Verlag, 22009), 203, for example, maintains the dependence on Jesus' tradition: 'Hier 
There are some possible terminological connections with the text of the writings of the prophets Isaiah and Jeremiah as well which will be referred to in the following two subsections.

\section{2}

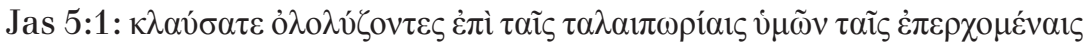

'Come now, you rich, weep and howl for the miseries that are coming upon you.'

The word that interests us in Jas 5:1 is another New Testament $h a$ pax legomenon, namely the verb ỏ $\lambda \mathrm{o} \lambda \hat{\zeta} \zeta \omega$, 'howl, lament' ${ }^{55}$ In the Septuagint, it occurs, only in the prophetical books and always in the negative sense, ${ }^{56}$ a total of 21 times, of which 13 are found in Isaiah and 3 in Jeremiah. It is typical of the Greek translation of the book of Isaiah to use the present imperative 2 nd pers. pl. pres. or aor. $(10: 10 ; 13: 6 ; 14: 31$; $15: 2,3 ; 23: 1,6,14 ; 24: 11 ; 52: 5) .{ }^{57}$

In the Old Testament prophecies, this verb is related primarily to the enemies of the chosen people ${ }^{58}$ who will be punished with various disasters in the day of the Lord's judgment ${ }^{59}$ and the howling and lamenting will be their only response to this, as, for example, Isa 13:6

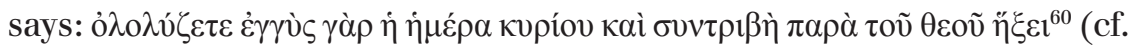
Isa 14:31; 15:2-4; 23:1; Jer 31(48):20; Amos 8:3 LXX; Joel 2:1). Against this Old Testament background, it can be concluded that James treats the rich as enemies who should howl and lament over their behaviour until punishment would come. ${ }^{61}$

\section{II.3}

Jas 5:5

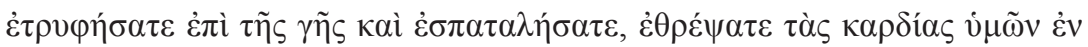
$\dot{\eta} \mu \varepsilon \dot{\varepsilon} \alpha \alpha \varphi \alpha \gamma \tilde{\eta} \varsigma$

lässt sich mit guten Gründen vermuten, dass Jakobus auf die dortige [in Matt 6:19f.; Luke 12:33, JP] Jesustradition rekurriert.'

ly'.

Cf. Hartin, James, 226; Johnson, Letter, 298-299.

In the Greek book of Jeremiah, the only impr. pres. 2. pers. pl. is in Jer 31:31.

Chaine, L'épitre, 114: 'Il est d'un usage fréquent dans les invectives: Isaïe contre Babylone, les Philistins, Moab, Tyr (XIII,6; XIV,31; XV,2,3; XXIII,1), Jérémie contre Moab

(XXXI [hébr. XLVIII],20), Amos contre les riches (VIII,3).'

so 'Wail, for the day of the Lord is near and a destruction will come from God!'

61 Cf. Gryglewicz, Listy, 122. 
'You have lived on the earth in luxury and in self-indulgence. You have fattened your hearts in a day of slaughter.'

The phrase $\dot{\eta} \mu \varepsilon \rho \alpha \sigma \varphi \alpha \gamma \tilde{\eta} \varsigma$ can be found in LXX only in Jer 12:3. Here in connection with verses 1-2 the prophet Jeremiah asks Lord

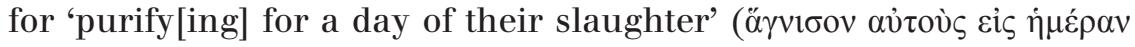
$\sigma \varphi \alpha \gamma \tilde{\eta} \varsigma \alpha \dot{\tau} \tau \tilde{\omega} v)$ the impious ( $\dot{\alpha} \sigma \varepsilon \beta \tilde{\omega} v)$ who commit acts of faithlessness

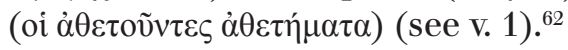

The expression 'a day of slaughter' in Jas 5:5 evokes prophetical pronouncements ${ }^{63}$ - mostly in Isa and Jer - depicting God's judgment over pagan nations or Jerusalem as a battle full of bloodshed and slaughtering of enemies (e.g., Jer LXX 32:34.64 (= 25:34); $27: 27$ (= 50:27); 12:3; 15:3; 28:40 (= 51:40); Ezek 21:15; Isa 30:25;65 34:2,6; 65:12) ${ }^{66}$ For them, as well as for the rich from Jas 5:1-6 who have become - with their misconduct - the actual enemies of Lord, the only Judge (Jas 4:12; cf. 5:9), 'a day of slaughter' is a day of judgment when their fate will be like the fate of sheep led to the slaughter (cf. Psalm 43:23 LXX; Zech 11:4,7; Isa 53:7; Jer 28:40 LXX) ${ }^{67}$

The verb $\tau \rho v \varphi \alpha ́ \omega$ should not be left unnoticed here ${ }^{68}$ because of its being New Testament hapax legomenon in Jas 5:5 and its occurrence only in three places in LXX, one of which is in Isa. But unlike the two other verses, Nehemiah 9:25 and Sir 14:4, in Isa 66:11b ${ }^{69}$ it is used

62 Allison, Commentary, 683 gives the possible reasons of the alterations in James' text against Jeremiah's version.

63 Johnson, Letter, 303-304: 'This image is itself complex. It builds on the ordinary method of providing food in an agricultural context, namely by slaughtering animals (see Ps. 43:23; Prov 7:22; Isa 53:7). But in the prophets, this quotidian and ritual activity became the image for divine judgment on evildoers (see Zech 11:4,7; Isa 34:2,6; 65:12; Jer 15:3; 19:6; 32:34).'

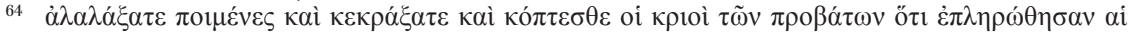

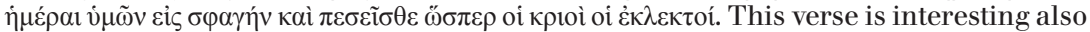
for the reason that with the verb $\dot{\alpha} \lambda \alpha \lambda \alpha \dot{\alpha} \alpha \tau \varepsilon$ (impr. aor. 2. pers.) it translates the Hebrew ילל just like ỏ $\lambda \circ \lambda \hat{\zeta} \zeta \varepsilon \tau \varepsilon$ in Isa 13:6 (see above).

65 Interestingly in the Hebrew version of Isa 30:25 we find a phrase the day of the great

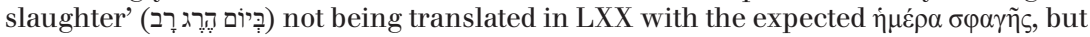

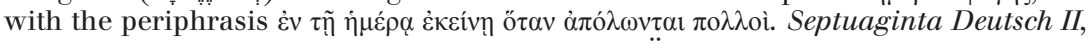
2585 characterizes it as 'freie, aber sinngemäße Übersetzung'. Vlková and Plátová, Izaiás, 192 surprisingly omits any comment on this verse.

${ }^{66}$ Cf. Chaine, L'épitre, 118; McKnight, Letter, 395; Hartin, James, 230.

${ }_{67}$ Maier, Brief, 208: '[die Reichen] selbst das göttliche Gericht erleiden. Aber bis unmittelbar dahin, "noch am Schlachttag", haben sie ihr gottloses Leben fortgesetzt und sich nicht um ihre Rettung gekümmert.'

68 Danker, Lexicon, 357: 'live in luxury'.

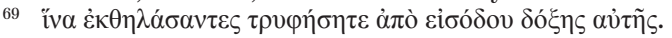


in a positive meaning connected with the rejoicing of Jerusalem (cf. $66: 10) .^{70}$

\section{Part III}

\section{Jas 1:10-11}

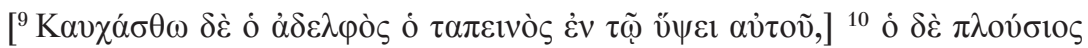

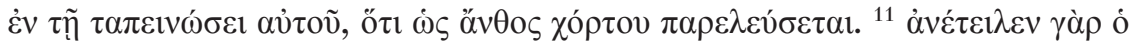

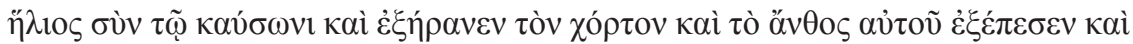

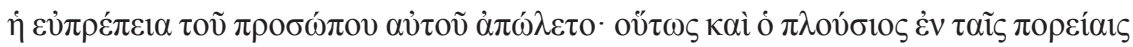

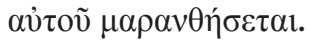

' $\left[{ }^{9}\right.$ Let the lowly brother boast in his exaltation, $]{ }^{10}$ and the rich in his humiliation, because like a flower of the grass he will pass away. ${ }^{11}$ For the sun rises with its scorching heat and withers the grass; its flower falls, and its beauty perishes. So also will the rich man fade away in the midst of his pursuits.'

\section{Isa 40:6-7}

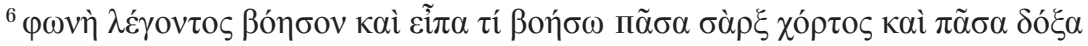

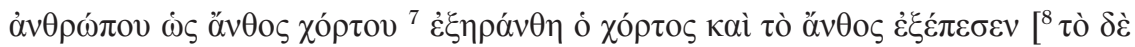

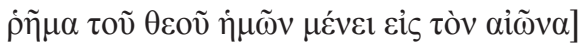

${ }^{6}$ A voice of one saying, 'Cry out!' And I said, 'What shall I cry?' All flesh is grass; all the glory of man is like the flower of grass. ${ }^{7}$ The grass has withered, and the flower has fallen, $\left[{ }^{8}\right.$ but the word of our God remains forever.]'

The rich man in Jas 1:10b is in his perishableness compared to 'a flower of the grass'. Although the motif of the transience of grass and flower also appears in other places of prophetical and wisdom literature,$^{71}$ the image as further developed in Jas 1:11 reminds us of the formulation from Isa 40:6-7. In the book of the prophet Isaiah, there is in this way expressed an ephemerality of all living creatures ${ }^{72}$ and

Cf. Chaine, L'épitre, 117.

71 See John Goldingay and David Payne, Isaiah 40-55. Volume I (London/New York: T\&T Clark, 2006), 82. Frankemölle, Brief 1, 248: 'Auch in Qumran ist der Topos der Vergänglichkeit im Kontext einer Auslegung von Ps 37 belegt (...), aber auch in der vorqumranischen, aber in Qumran verwendeten weisheitlichen Mahnrede 4 Q 185 unter deutlicher Verwendung von Jes 40,6-8; Ps 90,5-6; 102,15-16; Ijob 14,1f.'

72 Cf. Joseph Blenkinsopp, Isaiah 40-55. A New Translation with Introduction and Commentary (New York: Doubleday, 2002), 183. 
especially of human glory, ${ }^{73}$ being contrasted with the eternity of God's

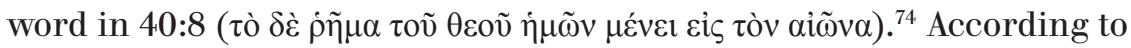
Isaiah, all humankind (and also its power structures, especially those of Babylon) is by its nature transient. ${ }^{75}$ This special state is now attributed to the rich by the author of the Letter of James. ${ }^{76}$ By using the words of the prophet Isaiah, James is in effect indicating that what the prophet had foretold now comes to fulfilment in the lives of the rich. ${ }^{97}$

The Isaiah passage is explicitly cited in the New Testament by 1 Peter 1:24f. ${ }^{78}$ with its original sense fully preserved, ${ }^{79}$ intending through the image of the withering grass 'to stress the concept of the enduring nature of the word of God'. ${ }^{80}$ Encouragement about the permanent validity of God's word is here denoted as the Gospel message is valid not only in the past, but also in the present time for the addressees of the letter. $^{81}$ The question here is whether the author of the Letter of James took his Isaianic material from 1 Peter. 'A comparison of Jas. 1:10-11 and I Pet. 1:24 makes it seem to be impossible that this could be true in the present case. ${ }^{92}$ The fact that 1 Peter quotes the Isaianic words

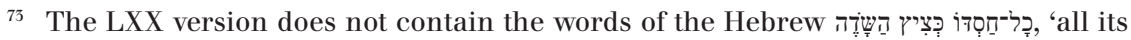

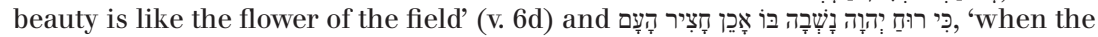
breath of the Lord blows on it; surely the people are grass' (v. 7bc). These words in v. 7 of LXX could be omitted by haplography (Blenkinsopp, Isaiah 40-55, 178; Vlková and Plátová, Izaiáś, 234). There are also other possible English translations of the word here, for example, Goldingay and Payne, Isaiah, 82: 'commitment', and Blenkinsopp, Isaiah 40-55, 178: 'splendour'.

74 Hubert Frankemölle, Der Brief des Jakobus. Kapitel 1 (Gütersloh: Gütersloher Verlagshaus, 1994), 249: 'Das Aussehen und die Existenz alles Irdischen ist relativ. So sicher ist diese Erfahrung immer wieder in der Natur bestätigt, so sicher 'wird' sich die Hinfälligkeit der menschlichen Existenz einstellen. (...) Dies ist ebenso sicher wie das Bleiben des Wortes Gottes in Ewigkeit nach Jes 40,8 (vgl. Jak 1,12c).'

Blenkinsopp, Isaiah 40-55, 183-184: 'But the message is not vague, moralizing statement about human frailty, as the combination 'grass' and 'flower' might suggest (cf. Ps $37: 2 ; 90: 5-6 ; 103: 15)$, and even less is it a lament for the helpless situation of the Babylonian diaspora from which the seer is speaking. It takes aim at the Neo-Babylonian Empire, then under terminal threat from the victorious progress of Cyrus II.' Cf. Goldingay and Payne, Isaiah, 81.

Cf. Chaine, L'épitre, LIX and 15; Maier, Brief, 68; Frankemölle, Brief 1, 248.

77 Hartin, James, 63.

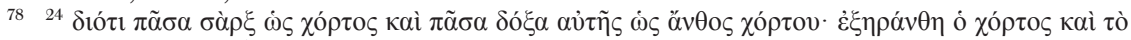

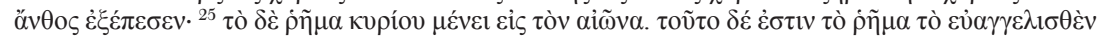

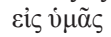

79 Cf. Chaine, L'épitre, LIX.

80 Hartin, James, 63.

81 Cf. Jan A. Dus, První list Petrưv (Praha: Centrum biblických studií and Česká biblická společnost, 2017), 91.

82 Morris, Investigation, 149. 
suggests that they could have been a part of Christian teaching before the letters of James and Peter were written. ${ }^{83}$

James does not explicitly refer to the book of the prophet Isaiah, but an allusion to some segments of Isa 40:6-7 seems to be quite clear. ${ }^{84}$

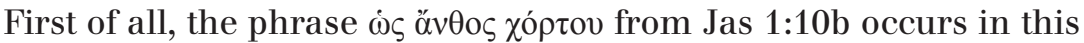
form in LXX only in Isa 40:6b. ${ }^{85}$ In the next verse of the two biblical writings we find both words ơv $\theta$ o

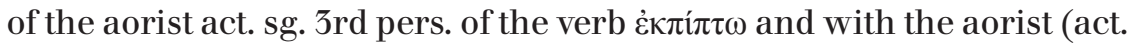
and pass. respectively) of the verb $\xi \eta \rho \alpha i v \omega:$

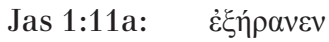

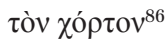

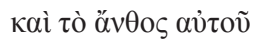
$\dot{\varepsilon} \xi \dot{\varepsilon} \pi \varepsilon \sigma \varepsilon v$,
Isa 40:7:
$\dot{\varepsilon} \xi \eta \rho \alpha ́ v \theta \eta$
ó $\chi o ́ \rho \tau o \varsigma$

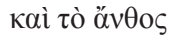
$\dot{\varepsilon} \xi \dot{\varepsilon} \pi \varepsilon \sigma \varepsilon v^{87}$.

Therefore, it can be said that as far as this verse is concerned, the author of the Letter of James not only knew the quoted septuagintal Isaianic phrase, but he also used it explicitly as a scriptural quotation without introducing it as such. ${ }^{88}$ Instead of using the words $\alpha$ óv $\theta$ o $\varsigma \dot{\alpha} \gamma \rho \circ \tilde{v}$ ('the flower of the field'), the Septuagint seems to uniquely ${ }^{89}$ translate the Hebrew phrase as צִיץ הָשָָָׁדה ('the flower of grass') Letter of James has used this translation. ${ }^{91}$ This is also confirmed by

83 Cf. Craig L. Blomberg and Mariam J. Kamell, James (Grand Rapids, Michigan: Zondervan, 2008), 64.

84 Cf. Blomberg and Kamell, James, 63; Gryglewicz, Listy, 59.

85 Allison, Commentary, 206: 'Although the use of plants to represent a short-lived exis-

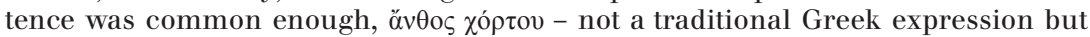
a Semitism, the equivalent of ציץ השדה - comes from Isa 40.6.'

86 Isaiah attributes the withering to the wind, not to the sun, or rather the sun's scorching heat, which is James' addition. Cf. Allison, Commentary, 208; McKnight, Letter, 101, n. 166.

${ }^{87}$ McKnight, Letter, 102, n. 174: 'Isa 40:7 has 'fade' or 'droop' (navel); James picks up the LXX translation here. In light of what James will make of the 'rich' at the end of v. 11, 'falls' is more devastating than dropping or fading.'

Cf. Hartin, James, 63 and 83; Johnson, Letter, 191.

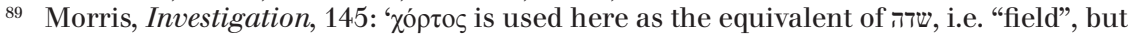

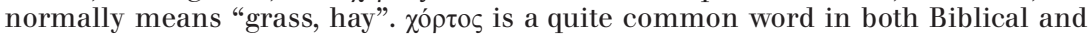
non-Biblical Greek, but nowhere else in Biblical Greek does it have the meaning "field" forced upon it. There is no other instance of its having been used to translate

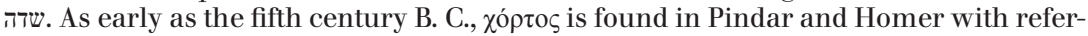
ence to any sort of a "feeding-ground", which could carry the connotation, of course of a "field". But no evidence is available of its continued employment in the latter sense in any area of Greek.'

90 Allison, Commentary, 206 n. 81: 'That is, we have here synecdoche.'

91 McKnight, Letter, 101, n. 167: 'The LXX rendering of Isa 40:6cd ("all flesh is grass [hatsir], all its goodnes like flowers [tsits] of the field [sadeh]") shows an irregularity 
the fact that the literal translation of the Hebrew term צִיץ הָשָָׁדָה with

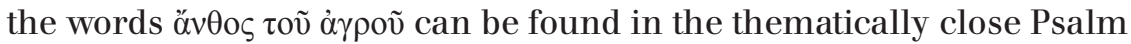

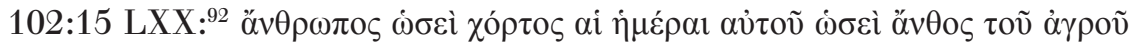

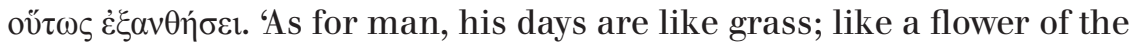

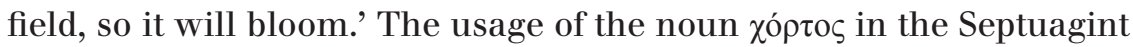
testifies that it refers 'not just to grass but to any greenery, just as the flower refers to any flower that grows in the meadow' ${ }^{93}$

In addition to the aforementioned terminological connections, Isa 40:2-9 and Jas 1:9-11 still share further lexical resemblances: ${ }^{94}$

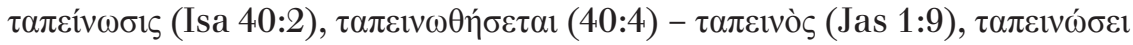

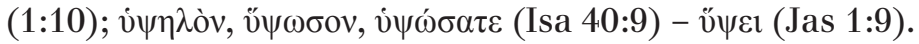

These similarities can also support the conclusion that in spite of the large circulation of the image of a withering herb used for the expression of the passing character of earthly existence, the author of the Letter of James in his verses 1:10-11 knew, used, and with regard to his intention slightly adjusted the 40th chapter of the book of the prophet Isaiah LXX, ${ }^{95}$ with their verbal proximity remaining the main argument. $^{96}$

\section{Conclusion}

In summary of our observations, it can be stated that the author of the Letter of James did not allude to the two Isaianic texts in a vague way or somehow en passant. These short texts from the letter dealt with

that James picks up, which confuses the interpretation: LXX renders both hatsir and

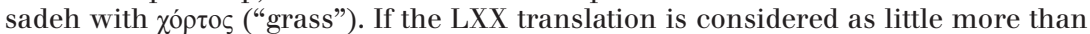
a poetic reuse of one term, then it becomes possible to see a more obvious analogy: comparison is made with the wildflowers and meadow flowers, like the anemone.'

Peter H. Davids, The Epistle of James. A Commentary on the Greek Text (Grand Rapids, MI: Wm. B. Eerdmans Publishing Co., 1983), 77 argues against any dependence of Jas 1:9-11 only on Isa 40:6-7 referring to its same closeness to Psalm 102:15-16 LXX. His opinion was convincingly disproved by Allison, Commentary, 197. Hartin, James, 63. Cf. Allison, Commentary, 206, n. 81; Chaine, L'épitre, 14-15.

94 Cf. Allison, Commentary, 197-198. On page 199 he also adds an interesting 'final remark concerning Jas 1.9-11 and Isa 40. The theme of the latter is preparing the

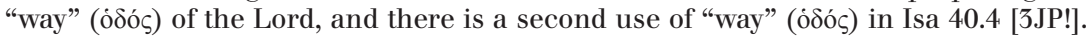

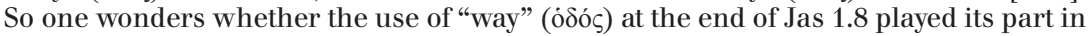
the process that led our author to Isa 40.'

95 Ralph P. Martin, James (Waco, Texas: Word Books, 1988), 23 suggests a certain possibility of an allusion of James to Mark 4:6, which seems to be its closest parallel. But Allison, Commentary, 210 presents four arguments, which make this opinion hardly convincing.

96 Frankemölle, Brief 1, 247. 
herein testify not only to the author's familiar knowledge of the book of the prophet Isaiah in the Greek translation of the Septuagint but also to the fact that in writing his letter he was influenced by it and he used and adjusted it in accordance with his purposes. ${ }^{97}$ This conclusion is based primarily on both verbal agreements and a certain similarity of the contexts in Jas 5:4 and Isa 5:9, and other terminological similarities in Jas 5:10-11 and Isa 40:6-7.

All direct quotations in the Letter of James come mostly from the Pentateuch $(2: 8,11,23)$ or from wisdom literature $(4: 6)$. The Isaianic phrasing in Jas 5:4 (and also the Jeremianic one in Jas 5:2) demonstrates that its author quotes explicitly also from the prophetical books of the Greek Bible. All of these facts also confirm the well-known suggestion that the author of the letter is not just well acquainted with the Old Testament, but, much more, he is permeated with it.

Faculty of Theology, University of South Bohemia in České Budéjovice Kněžská 8

37001 České Budéjovice Czech Republic E-mail: juliuspavelcik@seznam.cz

${ }_{97}$ We dare to presume that an analysis of other possible connections mostly in the form of indirect allusions between Jas and Isa would only support and confirm this conclusion. 